Onomastica Slavogermanica

XXXI

Wrocław 2019

DOI: $10.19195 / 0474-1471.31 .8$

\author{
STANISŁAWA SochacKa
}

Opole

\title{
Obraz społeczności i kultury wiejskiej w historycznej mikrotoponimii Śląska
}

Słowa kluczowe: toponimia, mikrotoponimia, Śląsk, cechy gwarowe

Nazwy terenowe są cennym materiałem do badań nad przeszłością wsi, jej kulturą i społecznością. Wyjątkową wartość mają na terenach pogranicznych, gdzie przenikają się wpływy różnych kultur i języków. Takim regionem etnicznie mieszanym był zawsze Śląsk. W dziejach politycznych obszar ten złączony był z państwem polskim, niemieckim i czeskim. Od strony zachodniej ziemie te były częścią historycznych Dolnych i Górnych Łużyc.

Owa wieloetniczna symbioza językowo-kulturowa znalazła odbicie w toponimii, którą traktuje się jako małe kompendium wiedzy o językowej przeszłości regionu i stosunkach ludnościowych. Jest to obszar szczególnie ciekawy dla językoznawców i dialektologów. Wśród prac poświęconych mikrotoponimii mało jest obecnie publikacji zajmujących się nazwami terenowymi Śląska1.

Niniejszy szkic jest próbą przedstawienia pewnych elementów „,wiejskiego obrazu świata" na podstawie historycznych mikrotoponimów śląskich polskiego pochodzenia. Nazwy niemieckie przywoływane są tu sporadycznie jako komponent uzupełniający.

Wiadomo, że cały zasób nazw terenowych historycznych i współczesnych jest ogromny i wielokrotnie przeważający liczbę nazw miejscowych na Śląsku. Łatwo się o tym przekonać sięgając do akt uwłaszczeniowych Śląskiej Komisji

1 Poza monografią R. Mrózka, System mikrotoponimiczny Śląska Cieszyńskiego, Katowice 1991, ukazało się kilkanaście artykułów materiałowych, na przykład K. Dejna, Terenowe nazwy ślaskie, „Onomastica” 2, 1956, s. 103-126; J. Burhardt, Polskie nazwy osobowe i terenowe pod Trzebnica i Miliczem w XIX wieku, „Śląski Kwartalnik Historyczny Sobótka” 1970, z. 1, s. 71-87; S. Sochacka, Polskie nazwy terenowe na XIX-wiecznych mapach katastralnych powiatu opolskiego, „Studia Śląskie” 26, 1974, s. 297-315; eadem, Wieś ślaska w świetle polskich nazw terenowych, „Śląsk Opolski” 10, 2000, nr 1, s. 1-6 n. 
Generalnej (Generalkomission für Schlesien) przechowywanych w Archiwum Państwowym Miasta Wrocławia i Województwa Wrocławskiego.

W latach 1722-1725 na polecenie dworu cesarskiego w Wiedniu na całym Śląsku przeprowadzono obliczenia szacunkowe stanu posiadania chłopów w poszczególnych osadach, zwany dzisiaj potocznie Katastrem Karolińskim, znajdującym się również w Archiwum Miasta Wrocławia. W kilkunastu tomach zarejestrowano tam setki polskich i niemieckich nazw pól, lasów, jezior i nazw osobowych.

Dwieście lat później (1925-1944) Niemcy zebrali około 100 tys. nazw terenowych w celach germanizacyjnych ${ }^{2}$. Część tego materiału została złożona w Archiwum Miasta Opola i po wojnie opublikowana w Stowniku etymologicznym nazw geograficznych Śląska ${ }^{3}$. Edycja ta stała się podstawą źródłową w niniejszej pracy. Dokumentacja archiwalna jest zatem przebogata od zarania XIII wieku i pozwala śledzić zmieniające się oblicze wsi.

Językowy świat wiejski jest kreowany według wyobraźni i potrzeb mieszkańców, których życie toczy się w zgodzie z prawami natury, jest wypełnione pracą w polu i w domu. Informacje o tym, w jaki sposób człowiek dawniej odbierał otoczenie, przekazują nam śląskie mikrotoponimy. Wyłaniają się z nich różne obrazy językowe, na przykład obraz natury i środowiska przyrodniczego, obraz kultury i gospodarki rolnej, obraz stosunków własnościowych, obraz ciężkiej codziennej pracy. Świat dawnych realiów naturalnym postępem cywilizacyjnym odchodzi w zapomnienie, a życie toczy się dalej. Doskonałym świadectwem polskiej pracy na tych ziemiach są nazwy terenowe i ich wartości poznawcze. A oto jak dawny świat został zapisany w nazwach akcentujących związek człowieka z przyrodą.

\section{Naturalne ukształtowanie krajobrazu}

Naturalne właściwości przyrodnicze, a więc rzeźba terenu, szata roślinna, świat zwierząt itp. były jednym z podstawowych motywów wyróżniania obiektów postrzeganych przez ludzi. To wszystko sprawiło, że nazwy topograficzne są nader żywotne. Są one bardzo zróżnicowane, gdyż charakterystycznych właściwości terenowych było wiele. Zakres stosowanych leksemów był wyjątkowo bogaty.

Przede wszystim zwrócę uwagę na pole semantyczne: urzeźbienie powierzchni ziemi (tak zwany relief).

2 A. Zobel, Die neue Sammlung der Flurnamen Schlesiens, „Mitteilungen für Namenkunde” 1957, z. 1, s. 13.

${ }^{3}$ Stownik etymologiczny nazw geograficznych Ślaska, t. 1-15, Warszawa-Wrocław-Opole 1970-2011. 


\subsection{Góry, pagórki, wzgórza}

Mamy tu archaizmy o proweniencji prasłowiańskiej, nazwy oparte na apelatywach staropolskich i gwarowych oraz formy nowszego pochodzenia:

Bardo (1238) — od wyr. *bardo 'góra, pagórek'; Chetm (Chelm 1783) od wyr. *chetm 'wzgórze, wzniesienie'; Czupel (1836) — od gw. czupel 'górka o ostrym wierzchołku'; Garbacina (Garbatzina 1860) — od wyr. garb 'wzniesienie'; Główki (Auf dem Hlowken 1782) — od wyr. główka $\longleftarrow$ głowa 'pagórek'; Goruszka (Pod Goruszka 1788) — od gw. goruszka 'górka'; Groń, Gronik (Na Groniku 1689) — od gw. groń 'góra'; Góra, Górka (Gorke 1820); Gradzik (Grondzik 1813) — od stpol. gradzik Ł grad 'zalesione wzniesienie'; Grzą, Grzęba (Grzemba 1920) — od stpol. grzęba 'górka, wzniesienie'; Krzepty (na Krzeptiech 1722) — od stpol. i gw. chrzebt, chrzept // krzept 'grzbiet góry'; Kepa (Kampe 1868) — od gw. kempa 'pagórek', też 'mała wyniosłość w terenie, zwłaszcza mokrym'; Kiczera (1736) — od gw. kiczera 'góra lesista'; Krępa (Krempa 1869) — od stpol. krępa 'grąd, wyniosłość nad wodami'; Kupa - od wyr. kupa 'wyniosłość, nierówność terenu'; Wierzch, Wierzchowina (Wierschowina 1864) —od stpol. wierzch, wirch 'spłaszczona część góry lub wyżyny'.

Sztuczne wzniesienia nosiły nazwy: Hałdy (Halden) — od wyr. hałda 'sztucznie usypana wyniosłość terenu, przeważnie związana z odpadami przemysłowymi'; Kopiec (Kopetz 1836) — od wyr. kopiec 'usypisko, wzniesienie'; Przysute — od gw. przysuć 'nasypać, zasypać'; Waty, Watki (1766) — od wyr. wat 'usypisko, nasyp, szaniec'; Wysypnica — od wyr. wysyp.

\subsection{Obniżenie terenu}

W tej grupie nazw widoczna jest opozycja góra-dół. Obrazują to formy przedsłowiańskie, staropolskie i gwarowe: Debrza (Dabri 1452) - od wyr. debra, debr 'wąwóz w dolinie, parów'; Bania - od stpol. i gw. bania 'dół'; Dolina, Dołek (Dolina oder Dołek 1920); Dót, Dót Gtęboki (1776); Gtębocz, Gtęboczek (Glembocz, Glumbotschke 1724) — od gw. głębocz 'głębia, dół'; Gruba (Na Grubi 1859) — od gw. gruba 'dół' (por. niem. die Grube 'dół'); Jama, Jamiska (Die Jame, Jamieska 1820); Jar (1945) — od wyr. jar 'głęboka dolina'; Jaźwa, Jaźwina (1702) — od gw. jaźwa 'jama, dół'; Padoty (Na Padoły) — od wyr. padót 'miejsce, teren położony nisko, nizina, dolina'; Pałaki (Palunken 1860) - od wyr. patak 'nizina'; Panew (Ponew 1900) — od gw. panew 'dól, obniżenie terenu'; Parów — od wyr. parów 'wąska dolina, wyżłobiona przez wodę'; Pławiska (Plawiska 1840) — od wyr. pława 'niska łąka'.

Na terenach górzystych pospolite były nazwy: Kociołki (Kocziolken 1805) od wyr. kociołek 'mały wąwóz, obniżenie terenu'; Kotliny (Kotlinen 1723) — od stpol. kotlina 'dół'; Żłobowina (Nad Żłobowinami 1830) — od wyr. żłobowina 'miejsce wklęsłe, wyżłobione, rozpadlina'. 


\subsection{Rodzaj gleby i podłoża}

Ważnym elementem krajobrazu wyróżnianym w nazwach była gleba, jej podłoże i kolor: Bagna (Auf dem Bagna 1830); Bara, Barzyna — od stpol. i gw. bara, barzyna 'bagno, moczar'; Betki (Na Betki 1825) — od stpol. betk 'bagno'; Bielica (An der bielitz) — od wyr. bielica 'mokradło, bagno'; Brynek (Breneh 1683) — od wyr. *breń 'błoto, glina'; Chechło (Chechel 1300) — od gw. chechto 'mokradło'; Dzierżno (villa Dziersno 1678) — od stpol. i gw. dzierg, dziarg 'ziemia piaszczysta', też 'piasek grubo ziarnisty'; Glinka (1864); Glazówka (Glozek, Glasowka) — od wyr. głaz 'kamień'; Grudynia (Grudina) — od wyr. gruda 'bryła ziemi', też 'sucha nierówna ziemia'; Itownica (Illownitz 1566) — od wyr. it 'urodzajna gleba'; Jełowa (Jellowa 1742) — od gw. jet 'ił'; Kaleja (1900) — od gw. kalej 'błoto, muł'; Kaliska, Katy (Kaly, Kalisken 1835) — od stpol. kat 'błoto'; Kaługa (Kaluga 1945) — od stpol. i gw. kaługa 'kałuża, błotnista ziemia'; Kamieńszczak (Kaminsczok 1874); Krzemnik (1536) — od wyr. krzem 'odmiana piasku'; Kujawy (Kujawy 1531) — od wyr. kujawa 'wydma piaszczysta', też 'miejsce jałowe i nieurodzajne'; Lędziny (Lendzini 1242) — od wyr. *lędo 'ziemia nieurodzajna', także 'wysychające błota, pokryte krzakami'; Lichynia (Lichan 1223) — od wyr. lichy, tj. 'licha ziemia'; Łacha (Lacha 1825) — od stpol. tacha 'teren bagienny, woda stojąca'; Lawiska (Lawischke 1860) — od stpol. tawa 'mielizna, bagno'; Łegi (Lang 1871) — od stpol. tęg 'podmokły grunt'; Mlaskawka (1879) — od gw. mlaskawka 'grunt grząski'; Młaka (Na Młakach 1840) — od gw. młaka 'bagno'; Nakło (Auf dem Naklo 1723) — od stpol. *nakło 'błotniste miejsce'; Ochaby (in Ochab 1300) — od stpol. ochab 'bagno, trzęsawisko'; Ochodza (zu Ochodzo 1719) — od gw. ochodza, ochoza 'miejsce, które trzeba obejść', też 'bagno, moczar'; Oparzelisko (Mittel Oparzeliska 1900) — od wyr. oparzelisko 'miejsce grząskie, bagniste', Otrzęsie (Otrzinsche 1822) — od gw. otrzęsie 'teren grząski'; Parzyska (1874) — od gw. parzysko 'bagno'; Piaski (Piosken 1805); Pierściec (Perstczy 1550) — od stpol. pierść 'kurz, proch'; Pizak (Pizok 1841) — od gw. pizok 'glina, ziemia dzika'; Pruchna (Prochna 1300) — od wyr. próchno 'próchnica'; Rędziny (Rędzina 1845) — od wyr. rędzina 'urodzajna gleba'; Ruptawa (1300) — od gw. rupieć 'kamieniste podłoże'; Skała (Mała Skała 1788) — od wyr. skała; Szczyrk (1925) — od gw. szczyrk, szczerk 'żwir, drobne kamyki'; Twardawa (Twardoua 1223, Na Twardym Polu 1723) — od wyr. twardy (na przykład grunt); Wapienica (Wopienica 1830) — od wyr. wapienica 'wapienna gleba'; Żużelina (Susselina 1930) — od wyr. żużel 'żwir, piasek'; Żelazna (Selazna 1223) — od wyr. żelazo, tj. 'żelazisty grunt'.

Wiele mikrotoponimów informuje o zabarwieniu i kolorze środowiska przyrodniczego, na przykład biały (Białociny, Bielinek), czarny (Czerniawa), ćmawy 'ciemny' (Ćminy), czerwony (Czerwionka - od gw. czerwiony 'czerwony'), zielony (Zieleniec), świny ‘szary’ (Swinebrudki), jasny (Jasna Góra).

Obiekty wyróżniające się bliżej nieokreślonymi kolorami nazywano: Łata (Lata 1830); Plama // Plana (Plama 1920, Plana - laskie) — od wyr. plana 'plama'; Pleszyna (Pleschine) — od wyr. plesz 'miejsce gołe, przeświecające w polu'; Pleśnianka (Pleśnionka 1830) — od wyr. pleśń, tj. 'w kolorze pleśni'. 


\section{Obszary leśne i zakrzewione}

Szata roślinna jako ważna i szczególnie wyróżniająca się w naturalnym krajobrazie była częstym i wyrazistym motywem nazewniczym. Nazwy odroślinne stanowią jedną trzecią całości nazw topograficznych. W nazwach zarówno miejscowych, jak i terenowych bazami nazewniczymi były: większe i mniejsze zbiorowiska leśne, pojedyncze drzewa, krzewy, zarośla, rośliny polne i dziko rosnące. Znajdujemy wśród tych nazw najczęściej:

\subsection{Określenia ogólne i zbiorowe:}

Bestwina (z Bestwyny 1492) — od gw. best 'bez'; Bór, Borek (Boreck 1784) — od wyr. bór 'las mieszany'; Brzezie (Brischie 1865) — od wyr. brzezie 'zagajnik brzozowy'; Bucze (Bosche 1779) — od gw. bucze 'buczyna'; Bzie (Bzie 1467) — od gw. bzie 'zarośla bzu'; Chebzie — od gw. chebd, chebda, chebdzie 'skupisko bzu dzikiego'; Chabowiec (Chabowetz 1864) — od gw. chabie 'chwasty, korzenie'; Chróścina (1223) — od stpol. chróścina 'gąszcz, zarośla, wiklina'; Cisie - od wyr. cisie 'lasek cisowy'; Czarnolesie // Czarny Las, tj. 'ciemny las'; Dąbrowa (Dambrowe 1723) — od stpol. wyr. dąbrowa 'las dębowy'; Gaj (Goj 1788) — od stpol. wyr. gaj, gw. goj 'zagajnik'; Glogowiec (Glogowetz 1300) — od wyr. głogowiec 'lasek, zagajnik głogowy'; Głożyna (Glasin 1874) — od wyr. głożyna 'głogowina'; Grabie (1722), tj. 'skupisko grabów'; Gwoździec (Gwozdziecz 1592) — od stpol. gwozd // gozd 'las'; Jaworze (1722) — od gw. jaworze 'las jaworowy'; Jedlina (1587) — od wyr. jedlina 'gaj jodłowy'; Knieja (Kniea 1297) — od stpol. knieja 'dziki, gęsty las'; Lipie (1887) — od wyr. lipie 'las lipowy'; Leszcze // Lyszcze (1612) — od wyr. gw. leszcze 'zbiór leszczyn', por. też gw. leska 'leszczyna'; Malinie (malina); Olszyna (Olssyna 1723); Orzesze (Orziesche 1386); Rokicie (Rokycze 1455) — od gw. rokicie 'skupienie rokit (wierzb)'; Sośnie (1939); Świbie (1687) — od wyr. świbie 'zbiór świb // świd'4; Świercze (1679) — od gw. świercze 'las świerkowy'; Świerkle (Swirkle 1830) — od gw. świerkle 'zbiór świerkli, to jest świerków'5; Topoliny (1830) — od gw. topolina 'gaj topolowy'; Wierzbie (1830). Odmianą wierzby jest koźlina, stąd nazwa Koźliniec (im. Koźliniek 1841).

W zaprezentowanym zestawieniu nie zostały wyszczególnione wszystkie gatunki drzew i krzewów. Znane drzewo iglaste modrzew zachowało dwie formy gwarowe: brzym (Brzim 1930) i moderz (Stary Moderz 1865). Podobnie drzewo jesionowe w nazwach śląskich utrwaliło się jako jasień: Jasień (1594) i jasion: Jasiona (Jassona 1285).

${ }^{4}$ S. Sochacka, Polskie nazwy miejscowe i terenowe od podstawy szyba (*šiba) na tle porównawczym, [w:] Animizacja i apelatywizacja, red. Z. Abramowicz, E. Bogdanowicz, Białystok 2006, s. 231-240.

${ }^{5}$ H. Borek, Wyraz *świerkla na podstawie toponimii, „Prace Filologiczne” 25, 1974, s. 275-279. 
Archaizmem leksykalnym jest gw. jedła 'jodła': Jedłownik, Jedlina (1587) i osina $\leftarrow$ osa 'osika': Osina (Oschine 1722).

Spośród krzewów iglastych i liściastych kreatorzy nazw wyróżniali na przykład jałowiec: Jałowiec (1830); jarzębinę: Jarzabki (Jarzumbki 1723), jemiote 'krzew pasożytniczy rosnący na drzewach': Jemielnica (Gemelnici 1298); kalinę: Kalinczak (Kalinczoks 1805); tozę: Łozisko (1539) — od gw. toza 'krzew z rodziny wierzbowatych'; leski // laski : Lyski (1920) — od gw. lyski 'leszczyny'.

Uwagę ludzi przyciągały też krzewy cierniste, na przykład ciernie: Ciernie (Tirne 1203); kolec: Na Kolcu (1920), głożyna 'głóg': Głożyny (Glasin 1874); ostrężyny 'jeżyny’: Ostrężyna (Ostranza 1264); tarniny: Tarnica (Tarnicza 1687); szadykierz 'jeżyna': Szadykierz (Schadekierz Teich) ${ }^{6}$.

\section{Rośliny dziko rosnące}

W mikrotoponimii śląskiej produktywną bazą stały się rośliny dziko rosnące zawarte w nazwach, na przykład Bluszczów (Blussczow 1472) — od wyr. bluszcz 'roślina z dzięgielowatych'; Brzostowe (Brustawe 1743) — od wyr. brzost 'wiąz'; Bzduchy (Bsduchy 1865) — od wyr. bzduch // bździoch 'roślina o nieprzyjemnym zapachu'; Czerwiniec (Pod Czerwince 1890) — od wyr. czerwoniec 'pospolita nazwa mchu czerwonego'; Dębiczne (Dambiczne 1830) — od wyr. dębik 'roślina z rodziny różowatych'; Drabnik (Drzabnik 1865) — od wyr. drab, drabik 'roślina z rodziny mchów liściastych'; Mieczysko Dlugie (1830) — od wyr. miecz 'roślina leśna o wydłużonych mieczykowatych liściach i dużych barwnych kwiatach'; Mniszek (1900) — od wyr. mniszek 'roślina, Tithymalus lathyris Hill'; Mokrzyca (1861) — od wyr. mokrzyca 'roślina z rodziny goździkowatych, rośnie na suchych łąkach, w rowach, przy drogach'; Nosowiec (Nosowietz 1595) — od wyr. nos 'bodziszek cuchnący, roślina leśna'; Osetno — od wyr. oset 'roślina polna'; Ostrzyczna (Ostrziczna 1567) — od wyr. ostrzyca 'trawa rosnąca nad brzegami rzek, stawów'; Paprotnik (Paprotnick 1743) — od wyr. paproć 'roślina leśna'; Parzydla — od wyr. parzydto 'rzepik pospolity'; Rzepik (Na Rzepiku 1945) — od wyr. rzepik 'roślina dziko rosnąca w lasach' (por. parzydło); Sadzica (Sadzica Wiesen 1886) — od wyr. sadziec 'roślina konopiasta rosnąca na wilgotnych łąkach'; Sitna, Sitnik (1945) od wyr. sit 'sitowie'; Pszonki (Pszunke 1723) — od wyr. pszonka 'roślina z rodziny jaskrowatych'; Storczyki (Pod sorcziky 1865) — od wyr. storczyk 'roślina dziko rosnąca w wilgotnych lasach'; Szupnia (Szupna 1900) — od wyr. szupin 'roślina z rodziny motylkowatych'; Strzyńska (Strzinsko 1865) — od gw. strzyna 'trzcina'; Trzemesze (Tschimesche 1785) - od wyr. trzemcha 'czeremcha'; Udory (Udorien 1859) — od wyr. udora 'roślina dziko rosnąca'; Wąsowiec (Wanschowietz 1805) od wyr. wąsowiec 'roślina leśna, Ageratum'.

\footnotetext{
${ }^{6}$ A. Bańkowski, Szadykierz, „Onomastica” 1979, z. 1/2, s. 38-52.
} 


\subsection{Rośliny lecznicze}

Mieszkańcy wsi „chrzczą” różne miejsca nazwami bliskimi sercu. Rośliny lecznicze są głęboko zakorzenione w tradycji ludowej ze względu na swą moc sprawczą i magiczne właściwości. Nic przeto dziwnego, że zostawiły one w mikrotoponimii wyraziste ślady, na przykład: Barwinkowa Góra (1643) — od wyr. barwinek 'roślina z rodziny toinowatych'; Bzowy, Bzinica - od wyr. bez, którego owoce mają właściwości lecznicze; Bławaciska (Blawacziska 1743) — od wyr. bławat 'chaber'; Drestka (1713) — od gw. drest 'rdest ptasi — znana roślina lecznicza'; Chwoszcz — od stpol. choszcz 'skrzyp polny', gw. chwoszcz; Chrzanowiec (Chrzanowic 1723) — od wyr. chrzan; Kłokocin (Clocochina 1300) — od stpol. kłokocina 'roślina leśna jesionowi podobna (krzew) o właściwościach leczniczych'; Kobiór (1417) — od gw. kobiór 'podbiał'; Lepik (1722) — od wyr. lepik 'roślina — przytulia północna'; Łopienica (Lopenica 1198) — od wyr. łopian 'roślina zielona o dużych liściach i kulistych kwiatostanach'; Maliniec (1723) — od wyr. malina 'krzew'; Marzaniaki (Marzanioken 1864) — od wyr. marzanka 'roślina leśna z rodziny marzanowatych'; Miętowisko (1945) od wyr. mięta 'znana roślina lecznicza'; Pokrzywnica (Hinter dem Pogrzyfnitza 1830) — od wyr. pokrzywa; Koprzywnica (de Koprsynviz 1339) —od stpol. koprzywa 'pokrzywa'; Różana Mała i Wielka (1689) — od wyr. róża 'roślina (krzew) o właściwościach leczniczych', por. też częste niem.: Rosenberg, Rosenthal; Rutki (Ruthki 1534) — od wyr. ruta 'ziele lecznicze'; Skrzypie — od wyr. skrzyp polny; Tatarak, też niem. Kalmusteich 'staw tatarczany'; Wrzosy — od wyr. wrzos 'roślina lecznicza, Colluna'. Nazwy oparte na powszechnie znanych ziołach leczniczych potwierdzają wiarę człowieka w lecznicze i magiczne właściwości roślin?

\section{Zwierzęta żyjące dziko}

Na podstawie mikrotoponimii i toponimii nietrudno zrekonstruować otaczającą mieszkańców faunę. W niedalekich lasach i wodach żyło sporo zwierząt, które zostały zauważone przez człowieka, na przykład Bobrowiec (1559) — od wyr. bóbr; Chrobacze (1657) — od wyr. chrobak 'robak'; Jaźwce (Jazwcze 1474) —od stpol. jaźwiec 'borsuk, niedźwiedź'; Jeleniak (1776) — od wyr. jeleń; Komorno (Comorno 1203) — od gw. komor 'komar'; Kozielawa (1934) — od gw. i stpol. koziet 'kozioł'; Niedźwiedzi Kąt (Niedźwiedzi Kondt 1583) — od wyr. niedźwiedź; Mysi Kat (Myszy Kunt 1826) - od wyr. mysz; Turawa (1708) - n. m. od wyr. tur; Wilcza (Nieder, Ober-Wilcza 1845) — od wyr. wilk; Wydrowiec (Wiedrowitz 1784) — od wyr. wydra; Zbijów (Zbiow 1586) — od wyr. zdeb 'żbik, pierwotnie Zdbijów'; Żabiak (Zabiok 1845) — od wyr. żaba; Jeżowa (1689) — n. m. od wyr.

${ }^{7}$ D. Lech-Kirstein, Nazwy ziót w polskiej toponimii, [w:] Jednotlivé a všeobecné v onomastike. 18. slovenská onomastická konferencia, Prešov 12.-14. septembra 2011, red. M. Ološtiak, Preszów 2012, s. 156-167. 
jeż; Pandrobie (Na Pandrobie 1950) — od wyr. pandrob 'szkodnik niszczący korzonki młodych roślin'.

Podstawami nazw terenowych często stawały się nazwy ptaków ${ }^{8}$. Wiąże się to z pozytywnym wartościowaniem tych zwierząt jako pożytecznych dla człowieka. Nawet ptactwo drapieżne wzbudzało respekt. Oto niektóre z nich: Jastrzab (1689), też niem. Habichtsberg; Kanica (Kanitza) — od wyr. kania 'dziki ptak'; Krogulec — od gw. krogulec 'jastrząb'; Orlik (1722), Orłowa (Orlowa 1723) — od wyr. orzet; Sępia Góra, niem. Geiersberg — od wyr. sęp, niem. Geier; Sokola Skała, niem. Falkenstein — od wyr. sokół, niem. Falk.

Dawne realia wiejskie częstokroć przywoływały nazwy motywowane nazwami ptaków pospolitych, na przykład Jaskóła, niem. Schwalbensteine - od wyr. jaskótka, niem. Schwalbe; Gawroniec (Gawronetz 1836) — gawron 'ptak z rodziny kruków'; Kruki Przednie, Kruki Zadnie (1776) — od wyr. kruk 'gatunek ptaka'; Gotębnik, niem. Taubenberg — od wyr. gotab, niem. Taube; Pliszka (die Pleiske) od wyr. pliszka 'ptak o siwej barwie'; Sikorka (Schikorka 1770) — od wyr. sikorka; Srokacz (Srokocz 1723); Wrona (Wrono 1900); Wróblowiec (Wroblowiec 1900).

Ludność wiejską cechuje bogate życie emocjonalne, stąd tyle nazw obrazujących więź z ptakami śpiewającymi, a także nocnymi i stadnymi, na przykład $C z y$ żyk, Drozdowa — od wyr. drozd; Dzięcioły (1689); Kawcze (Die kleine Kawcze, Die grosse Kawcze); Skowronek (Felde Skowronek); Stowik; Szczygłówka (Szczyglowka); Sowia Góra, Puchacz, niem. Eulenberg — od wyr. puchacz, niem. Eule 'sowa'.

Charakterystyczne dla polskiego krajobrazu są ptaki stadne, w tym wędrowne, takie jak: bocian (Bocianek, Bociniec); żuraw (Żurawiniec, niem. Kranich Wiese), a także ptactwo wodne i błotniste, na przykład czajka (Bagno Czaicze, Czajcze Łąki 1776); czapla (Czaplak 1652); stpol. orzoł 'czajka' (Orzle 1841).

W nazwach terenowych Śląska odnajdujemy kilka gatunków ryb, na przykład: Karasie — od wyr. karaś, Karpiec (Korpietzteich) — od wyr. karp; Lincze (Der Lincze Teichs 1864) — od wyr. lin; Piskorzowiec — od wyr. piskorz; Pstrążna - n. m. od wyr. pstrag; Sumina (Somina) — od gw. som 'sum'; płazów: Wężowite - od wyr. wąż Żabiak — od wyr. żaba.

Zwierzętom na pastwisku i w oborach dokuczały owady, o czym informują nazwy: Baczyska (Bunczisken), Komarcze (Die Comertze 1841); Susty (1830) od wyr. gw. sust 'chrabąszcz'; Muchowiec (1886) — od wyr. mucha.

\section{Kultura rolna i gospodarka}

Od najdawniejszych czasów Śląsk pokrywały ogromne obszary leśne. Dlatego też jednym z najstarszych zajęć ludności było zdobywanie ziemi pod uprawę.

${ }^{8}$ D. Lech-Kirstein, Nazwy ptaków w polskiej toponimii (przyczynek do onomastyki kulturowej), [w:] Mnohotvárnost a specifičnost onomastiky, red. J. David, M. Čornejová, M. Harvalík, Ostrava-Praha 2010, s. 304-312. 
Odbywało się to poprzez wycinanie, karczowanie i wypalanie lasów (tak zwana gospodarka żarowa $\left.{ }^{9}\right)$. Śladami tej ciężkiej pracy są nazwy oparte na leksemach bliskoznacznych.

Starym sposobem usuwania drzewostanu było czerszlenie - wycinanie ciosłą kory wraz z miazgą wokół pnia starych drzew, by usychały. Z tą czynnością powiązana jest śląska nazwa Czerśl, Czerśla (Tscherschel, Zerschel 1664) od ps. *črtiti 'nacinać'10.

Najwięcej nazw informuje o karczowaniu i wycinaniu lasów, na przykład Karczowina (Die Karcowine 1825); Łaziska, Lazak (Lazok 1865) — od stpol. łaz 'grunt uprawny po wykarczowanym lesie'; Osiek (Die grosse Osziek 1774) — od czas. osiec 'wyciąć las'; Poręba (Poremba Acker 1805); Przesieka (Preseka) od wyr. przesieka, przesiecz 'leśne przecięcie jako droga, granica'. Wyraz osiek i $\operatorname{przesiek}(a)$ są sobie bliskie, oparte na podstawie siec. Różnica dotyczy przedrostka: o-siek i prze-siek: Siagarnia (1920) — od gw. siag 'poręba, wyrąb lasu'; Plenisko (1788) — od wyr. plenisko 'miejsce wytrzebione pod uprawę'; Trzebnik, Trzebiel — od wyr. trzebić 'karczować las'; Wyrabiska (Rambisken 1841) — od wyr. wyrab 'karczunek'; Rąbek, Rąbacz — od wyr. rąb 'wyrąb, poręba'.

Rzadziej natomiast posługiwano się na Śląsku wypalaniem lasów niż karczowaniem. Nazw od podstawy palić, gorzeć, wędzić jest niewiele, na przykład Opalak (Opolak 1873), Opaleniec (Opalinietz 1871), Palenica (1945), Płomieniec — od wyr. płomieniec 'miejsce wypalone'; Pogorzelec (1685); Spalonki (Spalunki); Wędzina - n. m. (Wendzina 1679) — od gw. wędzić 'wypalać las'; Żarzyna (Zarzyna 1568) — od wyr. żarzyć.

Na terenach wykarczowanych powstawały pola zwane Niwami (Niwa 1723), Niwiskami (Niewiskie 1863); Nowiskami (Die Nowiskien 1772). Staropolskim określeniem nowego pola była Nowocina (Nowoczina 1836) jako synonim Nowin i Nowisk. Na tych gruntach zakładano osady zwane dziedzinami, por. n. Dziedzina, Dziedzinka (1743). Bliska znaczeniowo nazwie Dziedzina jest Swojszczyzna (Swojczisna 1723).

Chłopi śląscy nie tylko wycinali lasy, lecz także na gorszych ziemiach prowadzili gospodarkę odroślową. Pola z młodymi podrastającymi drzewkami nazywano: Młodzicze (Mlodzicze 1840), Młodziec; Szczepie (Sczepie 1723) — od wyr. szczep 'sadzonka, drzewko szczepione'; Zapusty (Sapuste Feld 1723) — od stpol. zapust 'młode drzewka rosnące dziko na miejscu ściętego drzewostanu'.

Jak sygnalizują niektóre nazwy miejscowe i terenowe, na Śląsku istniał też zakaz ścinania drzew, o czym mówią nazwy: Zapowiednik, Trzecia Zapowiedźod wyr. zapowiedź 'zakaz ścinania drzew, wypasu bydła i polowania'.

${ }^{9}$ Z. Zierhofferowa, K. Zierhoffer, Refleksy gospodarki żarowej $w$ polskim nazewnictwie, [w:] Nazwy własne a społeczeństwo, t. 2, red. R. Łobodzińska, Łask 2010, s. 107-116.

${ }^{10}$ A. Bańkowski, Ciekawe relikty leksykalne wśród staromazowieckich nazw polskich, ,Język Polski” 64, 1984, z. 1-2, s. 125-127. 


\subsection{Pola nieuprawne i wygony}

Ziemia leżąca odłogiem miała wiele określeń, na przykład Gluszyna (n. m. Glussina 1300), Gluszce, Gluszyska (Gluschze, Gluszisko) — od wyr. glusza 'miejsce puste, odłogiem leżące'; Gola (Die Guhle 1879) — od wyr. goły 'bezleśny'; Ług // Łęg (Im Lug 1860, Im Lęg) — od wyr. tug // tęg 'ugór'; Pleszyna — od wyr. pleszyna 'miejsce gołe, przeświecające w lesie'; Płoniny (1830) — od wyr. płony 'nieurodzajny', plonia 'ugór'; Przyłogi - od wyr. przyłóg 'ugór'; Odtogi - od wyr. odtóg 'ugór'; Pustki — od wyr. pustka 'miejsce puste'; Starzyna (Starzina) — od gw. śl. starzina 'stary grunt od dawna odłogiem leżący'; Surowina (Surowine 1830) - od wyr. surowy 'niezagospodarowany grunt'; Ugorna, Ugorzyca - od wyr. ugór; Wydmuchowiska - od gw. śl. wydmuchowisko 'teren bezludny, dziki'; Zagwiździe — od wyr. zagwiździe 'teren odległy, gdzie gwiżdże wiatr'; Wypędów (Wypandów 1845) — od gw. wypęd 'wygon, pastwisko'.

Wiele różnych terminów ukrytych w nazwach odnosiło się do pastwisk. Do wypasu bydła służyły błonie 'rozległe równiny trawą pokryte': Błonie (Auf der Blunie 1805), tak określane już od czasów wczesnośredniowiecznego osadnictwa. W okresie późniejszym posługiwano się nazwami: Pastwisko (Paswisko 1805); Pasterniki (Pasterniki 1840); Paśnik — od wyr. paśnik 'pastwisko'; Pascha (Die Pasche 1793) — od wyr. pasza 'miejsce porośnięte trawą, służące do wypasu bydła'; Pastwa (Pastwa 1920) — od wyr. pastwa 'miejsce porośnięte trawą'; Obora (Oborawiese 1805) — od gw. obora 'pastwisko'; Wolarka (An der Wolarka) — od gw. śl. wolarka 'wygon dla wołów'; Wywiat (Na Viviol 1865) — od gw. śl. wywiot 'wygon', też 'otwarty teren'; Pustki (1863) — od wyr. pustka 'pustkowie, miejsca niezagospodarowane'.

Przy wygonach i pastwiskach znajdowały się pomieszczenia dla pastuchów, tak zwane pastuszyńce: Pastuszyniec (Pastusyniec 1865). Ogrodzone pastwiska nazywano Koplami (Die Koppel) — od niem. die Koppel 'pastwisko', Koszarami (Kossar Wiese 1740), Stawiańcami (Stawiance 1836) — od wyr. stawianiec 'przenośna część zagrody dla owiec'; Strążkami (Strążek Wielki, Strążek Mały 1830) — od wyr. straga 'ogrodzone miejsce dla owiec'.

\subsection{Użytki rolne związane z podziałem gruntów}

Poczucie własności ziemi uprawnej od dawna było motywacją nazewniczą. Nazwy skoncentrowane wokół kultury rolnej zawierały określenia miar powierzchni ziemi. Wielość użytych do nominacji terminów obrazują nazwy: Ćwierci (Stwierci) — od wyr. ćwierć 'czwarta część przy podziale ziemi, też miara pola'; Działki (Dziolki 1605) — od wyr. działka 'wydzielona część pola'; Gony (Na Troje Gony 1855) — od wyr. gon 'miara długości pola, zagon'; Hubiane, Huby (1743) — od niem. die Hube 'łan'; Jagon (der Jagon 1595) — od wyr. jagon 'kwadratowa część lasu przedzielona alejami'; Jutra, Juterka // Juterki — od wyr. gw. śl. jutro 'miara 
pola równa jednej mordze'; Kąski (Kansken 1775) — od wyr. kasek 'mały kawałek pola'; Kwartnik - od wyr. kwarta 'cztery morgi, też 1/2 włóki'; Kwatery (Quatery 1905) — od wyr. kwatera 'działka, płaszczyzna okolona'; Kwintel (Die Quinteil 1863) — od wyr. kwinta, kwintal 'piąta część ziemi'; Łokieć (Lokec 1865) — od wyr. tokieć 'dawna miara długości, znana w całej słowiańszczyźnie, wynosząca 576 milimetrów, służąca do mierzenia tkanin'; Ean (Lan, Lon 1723) — od wyr. łan 'miara pola w różnych czasach różnej wielkości'; Miarka (Sześcimiarkowa) — od wyr. miarka 'ziemia wymierzona na sześć części'; Morgi (Na Morgi 1859) — od wyr. morga 'miara długości gruntu wynosząca w Polsce około 5600 metrów'; Ósmaczki (Łosmocki 1860) — od gw. śl. ósmak 'miara pola wynosząca osiem łanów'; Płoski (Plosky 1301) — od wyr. płoska $\leftarrow$ płosa 'pas ziemi mający 12 zagonów, stajanie'; Półtanek (Połannek) — od wyr. pótłanek 'zagon pół łana'; Póttornisko (Pultornisko 1700) — od wyr. póltorak 'zagon półtorałana'; Pręty (Prenty, Prentnik 1840) — od wyr. pręt kwadratowy 'miara powierzchni ziemi licząca 18,66 m²'; Stająko, Stajacze (Staiontze 1864) — od wyr. staja 'miara długości gruntu różna w różnych okolicach Polski'; Utrzyska (Utrziska 1840) — od wyr. utrzysko 'miara pola 25 arów'; Wiertel (Pienciwiertelowe) — od wyr. wiertel 'miara ciał sypkich i ciekłych, półkorzec, różnej wielkości w różnych krajach i dzielnicach'.

Nazwami obrazującymi inne jeszcze podziały gruntów były: Ablezunki od niem. die Ablösung 'odłączenie, zmiana', ablösen 'zwalniać', por. Ablezunek.

W 1865 roku wyszła na Śląsku ustawa Ablösung, która pozbawiała mieszkańców prawa korzystania z lasu w związku z wyprostowywaniem granic lasów. Resztki lasów wykarczowywano i ziemię dzielono wśród mieszkańców jako ekwiwalent za zniesione prawo leśne.

W mikrotoponimii śląskiej utrwaliło się wiele terminów rolniczych oznaczających w gwarze 'domierzone, dodane części pola', na przykład Domiarki (Domiarek 1805) — od wyr. domiarek 'domierzona, dodana część pola'; Namiarek (1679) — od wyr. namiarek 'pole otrzymane w wyniku podziału gruntu'; Napłatek (Naplatek 1864) — od wyr. naptatek 'kawał ziemi przylegający i będący dodatkiem do głównej posiadłości'; Połeć (Na Połecnej 1945) - od wyr. połeć 'kawałek'; Przyczepki (Die Prziszepki 1820) — od wyr. przyczepek 'pole dołączone do większej całości'; Przydatki - od wyr. przydatek 'grunt dodany do innej nieruchomości’; Przydziałki (Die Przidzialken 1723) — od wyr. przydziałek 'dodatkowa rola, dodatek'; Przymiarki (Przimiarki 1864) — od wyr. przymiarek 'wymierzony kawałek pola'; Wydziatki (Das Wydzialkifeld) — od wyr. wydziat, wydziatek 'to, co jest przydzielone, przydział'; Ucinki (Ućynki 1840) — od gw. ucinek 'ścinek, fragment pola'.

O polach oddanych w dzierżawę mówiono: Harenda - od gw. harenda 'dzierżawa'; Pachty — od niem. die Pacht 'dzierżawa, najem'.

O nazwach pól decydowały nie tylko miary gruntów, ale ich położenie i kształty. Gospodarze nie mieli swych pól w jednym kawałku. Były one rozrzucone w różnych miejscach. Pola i łąki przylegające do zagród zwano: Grzędami 
(Grzindi Wiesen 1769), Ogrodami (Ogrodi Feld 1892); Przysady (Pschyschady 1864) — od wyrażenia przyimkowego przy sadach; Ptoty (Ploth 1300), to jest 'teren przy płotach'; Przystronie (Przy strunie 1860) — od wyr. strona 'miejsce poza zwartą zabudową wsi'; Zawsie (Na Zawsie); Zadek (Na Zadku) — od wyr. zadek 'tylna część wsi'. Pola poprzecznie położone od strony wsi to Przeczoki (Przeczoken 1842), Przeczniczki bądź Ukosiny.

Wiele nazw określano w sposób metaforyczny. Punktem odniesienia były części ciała, na przykład Język — od wyr. język 'wąski teren', Kałduny (Kalduny 1743) — od wyr. gw. kałdun 'brzuch'; Kolanka (Kolonka 1865), a także akcesoria rolnicze - na przykład Łopata (Lopata 1830), Powróz (Powrus 1865), naczynia kuchenne — na przykład Miska (Miska Wiese 1860), Rondel, części ubrań — na przykład Rękaw, Rękawnik, Węzetki.

Pola wąskie i długie nazywano Smugami (Czmuga 1723) — od stpol. smuga 'miejsce wąskie i długie' bądź Pręgami (Prenke) — od stpol. pręga 'pas, smuga'. Nazwami kontrastywnymi były: Szerokie Pola, Wielkie Pola (In der Wielky Pole), Dtugie Dziaty (Dtugie Dzioły 1860).

Grunta położone na terenach nizinnych przeznaczono na łąki. Dla ochrony przed wodą ustawiano specjalne brogi na siano, tak zwane kawki (Kaffken 1844) lub kawy (Caven 1723). Błotniste łąki i trzęsawiska nazywało się kałami (Kehle 1839) lub kaliskami (Kolisken 1839). Łąki kośne zwały się trawnikami lub gwarowo trownikami (Trowniken 1844) oraz trawiskami (Trevisken 1832). Mokre, trawiaste miejsca przeznaczano na pastwiska, por. Morawa (Morawe 1831) i łąki, por. Morawiny (1836). Nazwami jednoznacznymi były Sieczne Łaki - od wyr. siec 'kosić trawę, zboże' i Kopidła (Kopidla genannt 1771) — od wyr. kopidło 'miejsca, łąki, gdzie stawiano siano w kopki'. Natomiast łąki, przy których dokarmiano zwierzęta, zwano Dowaniska (1823) — od gw. dować 'karmić zwierzęta'.

\subsection{Gospodarka uprawna i hodowlana}

Wieś śląska słynęła z tradycji sadzenia drzew owocowych, krzewów i uprawy roślin jadalnych, a także przemysłowych. Sady i ogrody, pola uprawne były kolejnym elementem środowiska gospodarczego będącego źródłem pożywienia mieszkańców. Pożywienie Ślązaków stanowiły, oprócz owoców leśnych (jagody, borówki czyli brusznice), grzyby (borowiki, zwane prawokami lub prawoczkami, kozaki, gw. kozoki, kałki, czyli siniaki), przede wszystkim warzywa i owoce ogrodowe.

Leksemy dotyczące tej dziedziny życia zostały utrwalone w mikrotoponimach ilustrujących:

- drzewa i krzewy ozdobne: Gruszka (Die Gruschke), też Kruszka (Die Krusken) — od stpol. krusza 'grusza'; Jabłacz (Jablocz, Joblocz) — od wyr. jabło 'jabłko', czyli 'miejsce właściwe do sadzenia i urodzaju jabłoni'; Liboskownia (1865) — od gw. śl. liboska 'śliwka'; Śliwa (Schliwa 1865); Trześnia (Za Trze- 
śnie, Za czesnÿ 1865) — od stpol. trześnia 'czereśnia'; Wiśnicze (Wiesnicz 1729); Winnica, też niem. Weinberg 'winna góra';

— rośliny jadalne: Grochowiec (Grochowitz 1793); Cebulowiec; Czosnek (1854); Grucki (Das Gruckenfeld) — od wyr. gruca 'owies'; Gotka (Golke genannt 1769) — od wyr. gołka 'rodzaj pszenicy, której kłosy nie mają ości'; Jęczmionka (Jenczmionkamühle 1860); Kapustnik (Kapuschnikwiesen), Kapuścisko (Kapustisko 1595); Knule (Na Knula, Acker, Wiesen) — od gw. śl. knule 'kartofle' $\leftarrow$ niem. die Knolle 'bulwa'; Jagielniak, Jagielnia (Jagielna-Mühle 1874) — od wyr. jagty 'roślina uprawna'; Makowiec (Makowietz Teich 1896) — od wyr. mak 'roślina uprawna'; Owiesno (Ovesnovo 1260), por. niem. Haferberg 'owsiane wzgórze'; Prosno (Proschen Stücke) — od wyr. proso, jagty;

- rośliny przemysłowe uprawne: Chmieliska (1558), też niem. Hopfenberg 'chmielna góra' — od wyr. chmiel; Konopowiec (Konopowiec Przedni i Konopowiec Zadni 1830) — od wyr. konopie; Lniska, Lniszcze (Illnisch 1520) — od wyr. len; Pasternak — od wyr. pasternak 'roślina uprawna stosowana jako pasza dla bydła'; Rzepiska (Die Rzepisken 1850) — od wyr. rzepa; Tabaczna Ścieżka, niem. Tabakensteig 'tytoniowa ścieżka';

- zwierzęta domowe: Barani Staw (Barani Teich 1805), Bykowina (Bickowina 1743); Browiniec (Browinitz 1534) — od gw. śl. browek 'wieprzek'; Cielęciniec (Czielentzinietz grund); Jagnięcy Jar, niem. Lammergrund; Kiędrozina (Kiedrozina) — od gw. kiędroz 'kiernoz, knur'; Kobyliniec — od wyr. kobyła; Końskie (Konske Wiesen 1820) — od wyr. koń; Kozia Góra; Krowiak (Krowiok 1865); Królikarze (Królikorze); Oślinka, też niem. Esels Berge 'ośle górki' — od wyr. osiet 'osioł'; Owczarnia (Offcziornia 1830); Świński Rów, niem. Saugraben 'ts.'; Wieprzyniec — od wyr. wieprz;

- ptactwo domowe: Bażantarnia // Fazanica - od gw. fazan 'bażant'; Gęsiak (Ganschiok) — od wyr. gęś; Gołębnik, niem. Taubenberg 'gołębia góra'; Kaczy Gradzik (Kaczegrundzik 1840) — od wyr. kaczka; Kokoci (Kokotschy 1865) — od wyr. gw. śl. kokot 'kogut', też Koczoty (Kotschoty 1837) — od gw. i stpol. koczot 'kogut'; Kurze Krzewie - od wyr. kura.

Z gospodarstwem domowym zaprzyjaźnione były jaskótki (Jaschkulke 1723) gnieżdżące się w oborze, tępiące muchy. Na pobliskich drzewach czatowały sroki (Schrocke 1723) porywające kurczęta. Za kominami i na polach świergotały świerszcze, gw. świercz (Schwiers 1824), a do okien dziobami stukały sikorki (Schikorke 1831).

Kataster Karoliński zawiera wiele materiału leksykalnego dotyczącego pożywienia mieszkańców. W lasach zbierano grzyby, takie jak: borowiki zwane prawokami lub prawoczkami (Prowatschke, Prowatzke 1724), kozaki zwane kozokami (Kosocke 1723), katki, czyli siniaki (Kalke 1935) oraz jagody (Jagoda 1724), borówki, czyli brusznice (Barufke 1841); warzywa, takie jak: kapusta (Kapuste 1724), czosnek (Tschoschnig 1829) czy pasternak (Pasternack 1829); owoce, jak gruszki (Gruska 1724), gnitki (Gnilke 1723), jabtka (Jablunke 1723 — od wyr. 
jabłonka). Poza tym jadano jaja, gw. jojka (Joytke 1722), żurek (Surke 1837), pito maślankę (Maslona 1722), kapate, czyli serwatkę (Kapalle 1726), a nawet gorzatkę (Gorsolcke 1723). Na święta pieczono kołacze (Kalotschke 1723).

\section{Kultura duchowa, obyczaje, przywary}

Świat duchowy mieszkańców wsi charakteryzują nazwy motywowane treściami nadnaturalnymi: religijnymi, parareligijnymi, demonicznymi, baśniowymi, legendarnymi itp. ${ }^{11}$

Dla ochrony przed złymi mocami przywoływano nazwy „sakralizowane”, zawierające człony: Boskie Oko, niem. Gottesauge, Boże Dary, Boża Główka, Boża Góra (Bozagora), Boże Pole, Boża Woda, Święty Krzyż, niem. Heiligkreutz, Święty Las, Święte Źródto.

Bliskie semantycznie tej grupie nazw są onimy: Dobra Woda, Na Dobrych (polach), Dobrzyń, Dobre Źródta, niem. Gute Quelle, Nowy Świat, Raj, Na Rajskim, budzące pozytywne skojarzenia.

Są też nazwy motywowane demonicznie: Czartorie // Czartoryje, Czarci Padót, Czarownica, Diablina, Piekto, Strach, Skidzieniec — od gw. skidzień 'wilkołak', Strzyganiec — od wyr. strzyga 'zmora', Widowiec (Widowietz Teich 1896) — od gw. wid 'zjawa, duch, widmo', Utoplec — od gw. utoplec 'strach wodny, wodnik, którego zamierzeniem jest jak najwięcej ludzi utopić'.

Do nazw odzwierciedlających trudne warunki bytowe należą: Gtodne, niem. Hungerfeld, Kłopot, niem. Neusorge, Krzywda (Im Krziwda Feld), Paskudna Góra, Troska.

Stosunek mieszkańców Śląska do spraw religijnych przedstawiają też nazwiska chłopów: Nawrot - od wyr. nawrot 'nawrócony, konwertyta'; Niewiara // Niewiora, Niewierzol, por. niewiara 'bezbożność', Paciorek, Pokuta.

Przytoczone nazewnictwo terenowe to tylko mały fragment większego zbioru. Na jego podstawie z powodzeniem można pokazać dawny zasięg języka polskiego, tym bardziej że zachowały się mapy katastralne dla każdej miejscowości.

Językiem ludności rodzimej była zawsze gwara. Ten lokalny język wskutek izolacji społeczności stał się „matecznikiem polskości”, kryjącym w sobie prawdziwe bogactwo i różnorodność w zakresie słownictwa, słowotwórstwa i morfologii.

W nazewnictwie toponimicznym nie znajduje odbicia pełny system dialektalny. Możemy tu jedynie mówić o pewnych cechach systemowych, ich chronologii i geografii. Utrwalane w nazwach zjawiska gwarowe dotyczą głównie fonetyki.

${ }^{11}$ A. Gałkowski, O niektórych nazwach „duchem podszytych” w onimii polskiej, włoskiej i francuskiej, „Onomastica” 55, 2011, s. 79-91. 


\section{Cechy dialektalne mikrotoponimii śląskiej}

\subsection{Cechy wokaliczne}

1. Wymowa pierwotnego a długiego (powstałego z samogłoski akcentowanej, wzdłużenia zastępczego lub ściągnięcia) jako monoftongicznego $o$, na przykład Na Czornym, Na Dzioły, Gordzielny, Grześniunka (o ścieśnione), Kowolikowe, Wywiot. Na Górnym i Dolnym Śląsku panowała dyftongiczna wymowa $a$ w postaci ou, na przykład Kloudtka, Miserouck.

2. Wymowa staropolskiego $o$ długiego prawie na całym Śląsku różni się zarówno od $o$, jak i $u$, choć do niego nieraz się zbliża, na przykład Dullny, Dulske, Dunkawa, Glimbutschke (Gtęboczki). Nagłosowe o- bywa labializowane protetycznym $t(u)$, na przykład Łosina (Olszyna), Łasicze (Osicze) z wtórnym unosowieniem, Łósmocki (Ósmaczki $\leftarrow$ osiem).

3. Wymowa $e \mathrm{w}$ grupie inicjalnej niekiedy zbliża się do $a$, na przykład $\mathrm{Cza}$ kan: czakać 'czekać', w nazwach zaś miejscowych mamy starą zmianą Domanyowo // Domanevo (1232-1234), Smardzevicy // Smardzovicy (1353). Każde e przed $N$ ulega wyraźnemu ścieśnieniu, zbliżając się do $y$, na przykład Czypek (Czepek), Kamiyń lub $i$ : Kamincke (Kamieńczyk), Na jelinie pole (Na Jelenie Pole), Przyrwa (Przerwa). Z kolei wtórna nosowość potwierdza się w nazwie Jezior, Jęzior (Jezioro), Przędziałek (Przedziatek). Brak przegłosu $e \rightarrow o$ mamy w nazwie Brzoźna (Brzeźna).

4. Wymowa $i, y$ : samogłoski te w historycznych zapisach były konsekwentnie odróżniane, ale zakres ich stosowalności był inny niż w języku ogólnopolskim. Na całym Śląsku po $\check{r}$ wymawiano $i$, na przykład Brzim, Krziwda, Przikopa, Przibylla. Samogłoska $y$ przed $N$ się podwyższała: Mlenczyska, Mlenczok.

5. Samogłoska $u \rightarrow e$ w nazwie Poledniowa.

6. Wymowa samogłoski *a. Na Śląsku samogłoska $a$ miała barwę rozszczepioną, jako: $(a+N)$ - Dambe, Oschambel, Poramba; $(u+N)$ - Kunty, Porumbke, Pod luncze; $(a+N)$ - Lanka, Kandziella (n. os.); $(o+N)-$ Kontzina, Gronschel (Grązel).

7. Wymowa samogłoski ę. Najczęściej rozkładane było e jako: $(e+N)-$ Kempa, Przirembel; $(a+N)$ - Lansce (Lężce), Gambus Stücke, Gawandtke (Gawędtka).

Nowsze nazwy terenowe ukazują wymowę $e>$ a: Gonsty Las, Gonschie ( $G q$ sie). Mamy też świadectwa wymowy ę $>u+N-N a$ cześć prónt (pręt) oraz ę $>$ $i$-Lingot (tęgot). Na terenie Górnego Śląska aż po Opolszczyznę panuje do dziś szeroka ustna wymowa ę jako a (bez rezonansu nosowego w wygłosie): Na Góra (Na Górę), Na Olschina, Na Brzezina.

Ponadto rzadko pojawiają się spółgłoski protetyczne $h \mathrm{i} j$ : Hadaschyki, Jadaminy. 


\subsection{Cechy konsonantyczne}

Podstawową cechą wyróżniającą nazwy terenowe na tle ogólnopolskim jest mazurzenie:

$\check{c}>c-$ Cupel, Copka, Kacmarzowe;

$\check{s}>s-$ Krusa, Marsolkowe, Sydlowsky;

$\check{z}>z-$ Kaluza, U Krziza, Zary.

Niekiedy nawet dziąsłowość traci $r z$ (tak zwane sycenie) — Jazumbek, Wies$b a, K s i k o p a$. Bywa też odwrotnie, kiedy $s z, r z(\dot{z}), c z$ występuje zamiast $s, z, c$. Zjawisko to nosi nazwę szadzenia i jest przejawem hiperpoprawności, na przykład Brzorsa, Czelencinietz, Czebula, Żerwatka (Serwatka).

Charakterystycznym zjawiskiem jest antycypacja miękkości spółgłosek palatalnych, na przykład Mainczok, Painskie doty, Okoin.

Wiele jest przykładów na wymowę frykatywną dawnego $\check{r}$ (palatalnego) jako rsz lub rż, na przykład Rzykossa // Rżykossa, Orsle (Orzle), Wierschowina, Kurpirsch. Grafia niemiecka regularnie zapisywała tę głoskę jako $r s$ lub rsch.

Głoska $\ell$ nie utraciła w mowie Ślązaków swojego przedniojęzykowego charakteru. Łatwo też ulegała asymilacji w odpowiednich warunkach. Przykładem jest nazwa Wodzisław $\leftarrow$ Włodzisław. Ale w nazwie Włodzisław zanikało nie $t$, lecz $u$, jak pisze A. Ropa ${ }^{12}$ w nazwach terenowych zanik $t$ potwierdzają: Bawacisko, Somcziska, Muniska, Unki (Ląki).

Oprócz tych głównych cech dialektalnych w nazwach odzwierciedliło się kilka występujących sporadycznie:

1. dysymilatywne rozbicie grup śř́, źr̆ lub $s r, z r, n r$ przez rozstawne $t, d$ : Strzo$d a$, Strzýbný (n. os.), Stroka, też wstawne -t- w przyrostkach: Czerwionatka (n. m. Czerwionka), Kloudtka;

2. dysymilacja $r-r>n-r:$ Czartoryja $\rightarrow$ Czantoryja;

3. uproszczenie grup spółgłoskowych typowe dla gwar: Kacmarziska, Gar$\operatorname{corz}$ (n. os.), n. m. Pierstna $\rightarrow$ Piersna, Żyrdniki $\rightarrow$ Żerniki.

\subsection{Cechy leksykalne}

Mikrotoponimy i toponimy często utrwalają wyrazy regionalne i gwarowe. Niejednokrotnie trudno odróżnić archaizmy od dialektyzmów, ponieważ w gwarach zwykle przechowywany jest stan dawnej polszczyzny.

Nazwy terenowe genetycznie łączą się z wyrazami pospolitymi będącymi osobliwościami semantycznymi. Najczęściej odnoszą się one do:

— topografii terenu: *bardo, *chetm, czupel, goruszka, kiczera, debrza, głebocz, jaźwa, pałak, panew, parów, bara, betk, bielica, breń, katuga, łacha, ława, tęg, młaka, *nakło, ochodza, otrzęsie, parzysko;

12 A. Ropa, Nazwa miejscowa Wodzisław, „Onomastica” 19, 1974, s. 62. 
- szaty roślinnej: best, chebd, chróścina, gwozd, knieja, brzym, moderz, jedta, osa, toza, leska, szadykierz, bluszcz, brzost, bzduch, czerwoniec, mokrzyca, sadzica, storczyk, szupnia, udora, choszcz, kobiór;

— kultury rolnej: czerszla // czerśla, taz, siagi, plenisko, nowociny, dziedzina, gola, głusza, pleszyna, płonia, pasternik, paśnik, paswa, huba, jagon, jutro, kwarta, kwinta, tokieć, morg, ósmak, płoska, utrzysko, wiertel, pręt, ablezunek, domiarek, namiarek, napłatek, połeć, przymiarek.

\section{Podsumowanie}

W artykule starano się pokazać wartości poznawcze historycznej mikrotoponimii śląskiej. Poświadczają one nie tylko dawną polskość tej ziemi, lecz są źródłem wiedzy o życiu i pracy mieszkańców tego regionu, o środowisku przyrodniczym, kulturze i języku.

Nazwy terenowe są wymownym świadectwem ciężkiej pracy na tej ziemi. Rękami chłopów śląskich karczowano lasy, przekopywano rowy (przetoki) odwadniające moczary i trzęsawiska. Tytułem do sławy były stawy rybne powstałe w XVI wieku z inicjatywy możnowładczego rodu Kurzbachów przybyłych z Miśni $^{13}$. Na nisko położonych rzeczkach sypano wały i groble zwane po staropolski gaciami. Na rzekach budowano zastawy, jazy, mosty. Ciężką pracą była gospodarka żarowa służąca do pomnożenia gruntów, karczowania i wycinania drzew. W lasach tworzono przesieki, to jest 'leśne drogi', budowano tartaki, młyny. Na polach uprawiano rośliny jadalne i przemysłowe. Śląskiego chłopa otaczały zwierzęta domowe i dzikie.

Niemal w każdej nazwie odbijają się właściwości gwary śląskiej. Ten obszerny zbiór nazw terenowych pokazuje, jak bogata i prężna była polszczyzna na Śląsku nawet w XIX wieku.

\section{Bibliografia}

Bańkowski A., Ciekawe relikty leksykalne wśród staromazowieckich nazw polskich, „Język Polski” 64, 1984, z. 1-2, s. 125-127.

Bańkowski A., Szadykierz, „Onomastica” 1979, z. 1/2, s. 38-52.

Borek H., Wyraz *świerkla na podstawie toponimii, „Prace Filologiczne” 25, 1974, s. 275-279.

Burhardt J., Polskie nazwy osobowe i terenowe pod Trzebnica i Miliczem w XIX wieku, „Śląski Kwartalnik Historyczny Sobótka" 1970, z. 1, s. 71-87.

Dejna K., Terenowe nazwy śląskie, „Onomastica” 2, 1956, s. 103-126.

${ }^{13}$ O rodzie Kurzbachów (Korzboków) zob. T. Jurek, Obce rycerstwo na Ślasku, Poznań 1996, s. 249-250; O. Strumiński, O spráwie, sypániu, wymierzániu i rybieniu stáwów, tákże o przekprzkopách, o ważeniu i prowádzeniu wody. Książki wszystkim gospodarzóm potrzebné, oprac. K. Kwaśniwska-Mżyk, Opole 1987. 
Gałkowski A., O niektórych nazwach „,duchem podszytych” w onimii polskiej, włoskiej i francuskiej, „Onomastica” 55, 2011, s. 79-91.

Jurek T., Obce rycerstwo na Śląsk, Poznań 1996, s. 249-250.

Lech-Kirstein D., Nazwy ptaków w polskiej toponimii (przyczynek do onomastyki kulturowej), [w:] Mnohotvárnost a specifičnost onomastiky, red. J. David, M. Čornejová, M. Harvalík, Ostrava-Praha 2010, s. 304-312.

Lech-Kirstein D., Nazwy ziół w polskiej toponimii, [w:] Jednotlivé a všeobecné v onomastike. 18. slovenská onomastická konferencia, Prešov 12.-14. septembra 2011, red. M. Ološtiak, Preszów 2012, s. 156-167.

Mrózek R., System mikrotoponimiczny Śląska Cieszyńskiego, Katowice 1991.

Ropa A., Nazwa miejscowa Wodzistaw, „Onomastica” 19, 1974.

Sochacka S., Polskie nazwy miejscowe i terenowe od podstawy szyba (*šiba) na tle porównawczym, [w:] Animizacja i apelatywizacja, red. Z. Abramowicz, E. Bogdanowicz, Białystok 2006, s. $231-240$.

Sochacka S., Polskie nazwy terenowe na XIX-wiecznych mapach katastralnych powiatu opolskiego, „Studia Śląskie” 26, 1974, s. 297-315.

Sochacka S., Wieś śląska w świetle polskich nazw terenowych, „Śląsk. Opolski” 10, 2000, nr 1, s. $1-6$.

Strumiński O., O spráwie, sypániu, wymierzániu i rybieniu stáwów, tákże o przekprzkopách, o ważeniu i prowádzeniu wody. Książki wszystkim gospodarzóm potrzebné, oprac. K. Kwaśniwska-Mżyk, Opole 1987.

Zierhofferowa Z., Zierhoffer K., Refleksy gospodarki żarowej w polskim nazewnictwie, [w:] Nazwy własne a społeczeństwo, red. R. Łobodzińska, t. 2, Łask 2010, s. 107-116.

Zobel A., Die neue Sammlung der Flurnamen Schlesiens, „Mitteilungen für Namenkunde” 1957, z. 1, s. 13.

\section{Słowniki}

Stownik etymologiczny nazw geograficznych Śląska, t. 1-15, Warszawa-Wrocław, Opole 1970-2011.

\section{The picture of the rural community and culture in Silesia's historical microtyponymy}

\section{Summary}

The author of the article examines the cognitive values of Silesia's historical microtoponymy. The article is based on the names published in Stownik etymologiczny nazw geographicznych Ślaska (Etymological dictionary of geographical names in Silesia). The analysed microtyponyms are a source of information about the life and work of people living in the region, about its natural environment, culture and language. An analysis of field names makes it possible to present some elements of the rural image of the world. It comprises names indicating the natural form of 
the landscape, forests and woodland areas, names of plants, wild animals, names associated with agriculture, with spiritual culture and customs. Most of the analysed names reflect the features of the Silesian local dialect.

Keywords: toponymy, microtyponymy, Silesia, dialect 